\title{
Clinical Characteristics of Diabetic Patients with Diabetic Retinopathy
}

\author{
Arnon Blum ${ }^{1, *}$ and Dorina Socea ${ }^{2}$ \\ ${ }^{1}$ Department of Medicine; ${ }^{2}$ Ophthalmologic Department, Baruch-Padeh Poria Hospital, Lower Galilee 15208 \\ Israel
}

\begin{abstract}
Abstarct: Background: Proliferative diabetic retinopathy is a consequence of retinal ischemia due to capillary occlusion resulting from damage to the retinal endothelium, and is associated with increased risk of cardiovascular morbidity and mortality.
\end{abstract}

\begin{abstract}
Methods: We randomly assigned seventy three patients with DM type II and grouped them according to their retinal proliferative disease (Group A - 25 patients [12 males], mean age $62.8 \pm 10.8$ years, no diabetic retinopathy; Group B - 25 patients [19 males], mean age $61.9 \pm 9.4$ years, non-proliferative retinopathy; and Group C - 23 patients [13 males], mean age $59.2 \pm 10.3$ years, proliferative retinopathy). Twenty three healthy subjects (14 males; mean age $44.3 \pm 11.6$ years) served as the control group. We studied their retinal vasculopathy status, height, weight, body mass index (BMI), waist circumference, age, endothelial function (flow mediated diameter [FMD\%] percent change) and their peripheral artery disease (ankle brachial index $[A B I])$.
\end{abstract}

Results: A significant difference was found between the duration of length of DM type II between patients without retinopathy [group A] ( $9 \pm 6$ years) and patients with non-proliferative retinopathy [group $B]$ ( $17 \pm 9$ years) ( $p=0.001)$. No difference in length of diabetes was observed between patients with non-proliferative retinopathy [group B] and patients with proliferative retinopathy [group $\mathrm{C}$ ] $(19 \pm 6$ years) $(\mathrm{p}=0.30)$. A significant difference was observed in $\mathrm{HgA} 1 \mathrm{C} \%$ between group A $(7.1 \pm 2.7 \%)$ and group B $(8.5 \pm 1.5 \%)(p=0.02)$. No such difference was noted between group $B$ and group $C$ $(8.5 \pm 1.6 \%)(p=0.98)$. Only 6 patients (out of 23 ) used insulin treatment in group A compared with 16 group $B$ (out of 25) and 17 in group $C$ (out of 25$)(p=0.004)$. All three groups of diabetic patients were older $(62.8 \pm 10.8,61.9 \pm 9.4,59.2 \pm 10.3$ years, respectively) than volunteers $(44.3 \pm 11.6$ years) $(p \leq 0.001)$, had a lower stature $(1.65 \pm 0.09,1.68 \pm 0.07,1.65 \pm 0.09$ meters, respectively) compared with controls ( $1.73 \pm 0.08$ meters) ( $\leq \leq 0.05)$, had a larger waist circumference $(110.04 \pm 14.17,108.88 \pm 13.00,109.30 \pm 13.49 \mathrm{~cm}$, respectively) than controls $(93.43 \pm 11.66 \mathrm{~cm})(\mathrm{p} \leq 0.001)$, and larger BMls $(30 \pm 6,29 \pm 4,30 \pm 5)$ compared with controls $(25 \pm 4)(p \leq 0.001)$. All diabetic patients had severe endothelial dysfunction measured by FMD\% $(-1.9 \pm 7.4,-3.3 \pm 9.2,-3.1 \pm 6.6 \%$, respectively) compared with the control group $(16.5 \pm 7.5 \%)(p \leq 0.001)$. ABI was within normal range in all patient $(0.97 \pm 0.18,1.14 \pm 0.24,1.03 \pm 0.28$, respectively), and in volunteers $(1.06 \pm 0.18)(p \geq 0.05)$. There was no significant change within the 3 subgroups of diabetic retinopathy patients in age, height, weight, BMI, or FMD\%.

Conclusions: All patients with DM type II had severe endothelial dysfunction, higher BMls, lower statures, larger waist circumferences; however they all had normal ABIs.

Keywords: Endothelial function, diabetic retinopathy, ABI.

\section{INTRODUCTION}

The earliest clinical signs of diabetic retinopathy are microaneurysms [1] and after 20 years of disease they are present in nearly all patients with DM type I [2] and in $80 \%$ of patients with DM type II [3]. Proliferative diabetic retinopathy involves the formation of new blood vessels, and this process carries an ominous prognosis for vision [1]. Patients who have had the disease for 15 years may develop proliferative retinopathy in up to $50 \%$ of patients with DM type I [2] and in $10 \%$ of patients with DM type II [3]. Epidemiological studies have shown that proliferative retinopathy predicts cardiovascular mortality and morbidity in both DM type I [4-7] and DM type II [8-12] populations. There is data suggesting that nonproliferative retinopathy could predict mortality (all

*Address correspondence to this author at the Poria Hospital, Lower Galilee 15208; Israel; Tel: 972-4-6658688; Fax: 972-4-6652681;

E-mails: ABlum@poria.health.gov.il, navablum@hotmail.com cause and cardiovascular) only in women with DM type II [13] while another study that followed 2103 DM type II patients for 7 years showed that only diabetic retinopathy (especially in its more advanced stages) is associated with an increased cardiovascular disease incidence independent of other known cardiovascular risk factors [14]. The mechanism of the association between diabetic proliferative retinopathy and increased incidence of cardiovascular morbidity and mortality raises questions about the ability to predict vascular disease progression (micro- and macrovascular) by non invasive means or by clinical parameters.

Our aim was to find an association between diabetic retinopathy staging (no-retinopathy, non-proliferating retinopathy, and proliferating retinopathy) and clinical characteristics and/or severity of systemic vascular responsiveness that will define each group and may assist in early detection of microvascular complications 
that eventually lead to blindness and cardiovascular events.

\section{METHODS}

We randomly assigned seventy three patients with DM type II (25 patients [12 males], mean age $62.8 \pm 10.8$ years, without diabetic retinopathy [group A], 25 patients [19 males], mean age $61.9 \pm 9.4$ years, with non-proliferative retinopathy [group B], and 23 patients [13 males], mean age $59.2 \pm 10.3$ years, with proliferative retinopathy [group C]) that came for a routine follow up visit in the ophthalmologic outpatient clinic. Twenty three healthy subjects (14 males; mean age $44.3 \pm 11.6$ years) served as the control group. On entry to the study an experienced ophthalmologist diagnosed retinopathy by fundoscopy after papillary dilatation, using a clinical disease severity scale [15]. Retinopathy was classified as follows: Group A - no retinopathy; Group B - non-proliferative retinopathy; Group C - proliferative retinopathy with intra-retinal hemorrhage and/or hard exudates. Twenty three healthy volunteers served as the control group. The study was approved by the internal review board of the hospital, and all participants signed a consent form before enrolment to the study.

\section{Clinical Characteristics}

Included age, gender, height, weight, Body Mass Index (BMI), (calculated by dividing weight in kilograms by height in meters squared), waist circumference (was measured at the level of the umbilicus), hemoglobin $\mathrm{A} 1 \mathrm{C} \%(\mathrm{HgBA} 1 \mathrm{C} \%)$, length of disease, and the need for insulin treatment. Vascular responsiveness was assessed by measuring endothelial function and using the ankle brachial index.

\section{Flow Mediated Diameter Percent Change (FMD \%)}

All measurements of brachial artery diameter and FMD were performed early in the morning, in a quiet and dark room and at controlled ambient temperatures between $20^{\circ} \mathrm{C}$ and $26^{\circ} \mathrm{C}$. Studies were conducted after an overnight fast of at least 10 hours (water was permitted), with the subjects supine and after 10 minutes of rest. The subject's right arm was comfortably immobilized in the extending position, allowing for ultrasound scanning of the brachial artery 5-10 cm above the antecubital fossa. In each examination, recording of vessel images were followed by inflation of a cuff to supra-systolic pressure (40 to 50 $\mathrm{mmHg}$ above systolic pressure) for 5 minutes. Then the cuff was deflated and the brachial artery diameter was imaged and recorded for 3 minutes. FMD\% more than $10 \%$ is considered a normal response. Lower than $10 \%$ FMD\% reflect endothelial dysfunction, which means a high likelihood to develop cardiovascular event in the future. Subjects with negative FMD\% results (the artery is constricted after stress and not dilated as was expected) have the worst prognosis.

\section{Ankle-Brachial Index (ABI)}

An $A B I$ was performed while the patient was supine and measurement of the systolic blood pressure in all four extremities was done. To measure an ankle systolic pressure, a standard adult blood pressure cuff was placed around the ankle just above the malleoli. While using the Doppler flow-meter to monitor the signal from the posterior of the anterior tibial artery, distal to the cuff, the cuff was inflated to a pressure approximately $30 \mathrm{~mm} \mathrm{Hg}$ above the systolic pressure to occlude flow temporarily. As the cuff was slowly deflated (2 to $5 \mathrm{~mm} \mathrm{Hg} / \mathrm{s}$ ), the pressure at which the Doppler flow signal was first heard and recorded was the ankle systolic pressure. An ABI was calculated by dividing the ankle systolic blood pressure by the greater of the two systolic upper extremity systolic blood pressures. An ABI of $>1.0$ was normal. An ABI of 0.5 to 0.9 was indicative of injury to a single arterial segment. $A n A B I$ of $<0.5$ was indicative of severe arterial injury or injury to multiple arterial segments.

\section{Statistical Analysis}

Students' $T$ test and Chi square test were used for categorical variables and one way ANOVA was used for continuous variables to compare differences between patients in different stages of diabetes mellitus. T-tests included two tailed distribution with paired and two sample unequal variance.

\section{RESULTS}

Seventy three DM type II patients were recruited to the study after signing a consent form. We grouped them according to the ophthalmologic examination (fundoscopy) after papillary dilatation, using a clinical disease severity scale [15]. There were 25 patients in Group A (12 male, mean age $62.8 \pm 10.8$ years), 25 patients in Group B (19 males, mean age 61.9 \pm 9.4 years), and 23 patients in Group C (13 male, mean age $59.2 \pm 10.3$ years). In the control group there were 23 healthy subjects ( 14 male, mean age $44.3 \pm 11.6$ years) $(p \leq 0.001)$ (Table 1). Patients had a lower stature 
Table 1: Clinical Characteristics

\begin{tabular}{|c|c|c|c|c|}
\hline & Controls & Group A & Group B & Group C \\
\hline No. & 23 & 25 & 25 & 23 \\
\hline Men & $14(60 \%)$ & $12(48 \%)$ & $19(76 \%)$ & $13(56 \%)$ \\
\hline Age (years) & $44.3 \pm 11.6$ & $62.8 \pm 10.8$ & $61.9 \pm 9.4$ & $59.2 \pm 10.3$ \\
\hline P-value ${ }^{\star \star}$ & & $\leq 0.001$ & $\leq 0.001$ & $\leq 0.001$ \\
\hline Height $(\mathrm{cm})$ & $173 \pm 8$ & $165 \pm 9$ & $168 \pm 7$ & $165 \pm 9$ \\
\hline $\mathrm{BMI}$ & $25 \pm 4$ & $30 \pm 6$ & $29 \pm 4$ & $30 \pm 5$ \\
\hline P-value** & & 0.001 & $\leq 0.001$ & $\leq 0.001$ \\
\hline Waist Circumference & $93 \pm 12$ & $110 \pm 14$ & $109 \pm 13$ & $109 \pm 13$ \\
\hline P-value** & & $\leq 0.001$ & $\leq 0.001$ & $\leq 0.001$ \\
\hline Duration of DM (y) & & $9 \pm 6$ & $17 \pm 9$ & $19 \pm 6$ \\
\hline P-value* & & 0.001 & 0.30 & \\
\hline $\mathrm{HBgA} 1 \mathrm{C} \%$ & & $7.1 \pm 2.7$ & $8.5 \pm 1.5$ & $8.5 \pm 1.6$ \\
\hline P-value* & & 0.02 & 0.98 & \\
\hline
\end{tabular}

$\mathrm{BMI}$ - body mass index.

DM - diabetes mellitus type II.

HBgA1C\%-hemoglobin A $1 \mathrm{C} \%$.

$P$-value ${ }^{*}$ - comparison between the groups of patients.

P-value ${ }^{* *}$ - comparison between each group and the control group.

P-value***- comparison between group 3 and group 1 .

$(165 \pm 9 \mathrm{~cm}, 168 \pm 7 \mathrm{~cm}, 165 \pm 9 \mathrm{~cm}$, respectively) compared with controls $(173 \pm 8 \mathrm{~cm})(p \leq 0.05)$, a larger waist circumference $(110 \pm 14 \mathrm{~cm}, 109 \pm 13 \mathrm{~cm}, 109 \pm 13$ $\mathrm{cm}$, respectively) than controls $(93 \pm 12 \mathrm{~cm})(p \leq 0.001)$, and a larger $\mathrm{BMI}(30 \pm 6,29 \pm 4,30 \pm 5$, respectively) compared with controls $(25 \pm 4)(p \leq 0.001)$ (Table 1). A significant difference was found in diabetes mellitus duration between patients without retinopathy [group $A$ ] $(9 \pm 6$ years) and patients in the non-proliferative retinopathy group [group $B](17 \pm 9$ years $)(p=0.001)$. No difference in length of diabetes was found between the non-proliferative retinopathy group [group B] and the proliferative group [group $C$ ] $(19 \pm 6$ years) $(p=0.30)$ (Table 1). A significant difference was observed in $\mathrm{HgA} 1 \mathrm{C} \%$ between group A $(7.1 \pm 2.7 \%)$ and group B $(8.5 \pm 1.5 \%) \quad(p=0.02)$. No such difference was noted between the non-proliferative group (group B) and the proliferative group (group C) $(8.5 \pm 1.6 \%) \quad(p=0.98)$ (Table 1). Only 6 patients in group A (out of 23) used insulin treatment, while 16 patients (out of 25) (group B) and 17 patients (out of 25) (group C) used it $(p=0.004)$ (Table 1). All diabetic patients had severe

Table 2: Vascular Measurements

\begin{tabular}{|c|c|c|c|c|}
\hline & Controls & Group A & Group B & Group C \\
\hline \hline Baseline Brachial & $36 \pm 6$ & $41 \pm 9$ & $38 \pm 7$ & $38 \pm 7$ Diameter $(\mathrm{mm})$ \\
\hline P-value** & & 0.01 & 0.20 & 0.26 \\
\hline FMD (\%) & $16.5 \pm 7.5 \%$ & $-1.9 \pm 0.18 \%$ & $-3.3 \pm 9.2 \%$ & $-3.1 \pm 6.6 \%$ \\
\hline P-value** & & $\leq 0.001$ & $\leq 0.001$ & $\leq 0.001$ \\
\hline ABI & $1.06 \pm 0.18$ & $0.97 \pm 0.18$ & $1.14 \pm 0.24$ & $1.03 \pm 0.28$ \\
\hline P-value* & & 0.01 & 0.17 & \\
\hline
\end{tabular}

FMD (\%) - Flow Mediated Diameter percent change.

$\mathrm{ABI}$ - Ankle Brachial Index.

$P$-value ${ }^{*}$ - comparison between the groups of patients.

$\mathrm{P}_{\text {-value }}^{* *}$ - comparison between each group and the control group. 
endothelial dysfunction measured by FMD\% $(-1.9 \pm 7.4 \%, \quad-3.3 \pm 9.2 \%, \quad-3.1 \pm 6.6 \%, \quad$ respectively $)$ compared with the control group $(16.5 \pm 7.5 \%)(p \leq 0.001)$ (Table 2). ABI was within normal range in all groups $(0.97 \pm 0.18,1.14 \pm 0.24,1.03 \pm 0.28$, respectively) with no significant difference from the volunteers' $A B I$ $(1.06 \pm 0.18) \quad(p \geq 0.05)$ (Table 2). No significant change was observed within the 3 groups of diabetic retinopathy patients in age, height, weight, BMI, waist circumference and FMD\% ( $p=$ NS for all) (Tables 1 \& 2).

\section{DISCUSSION}

We found that all patients with DM type II had severe endothelial dysfunction, higher BMls, lower statures and larger waist circumferences; however they all had normal ABls.

\section{Diabetic Retinopathy and Vascular Disease Progression}

Population based studies have shown that microvascular complications predict cardiovascular disease mortality in DM type I [15, 16] and type II [1720]. An 18 years follow up study found that proliferative retinopathy in both sexes and background retinopathy in women predicted all-cause, cardiovascular disease, and coronary heart disease death. These associations were independent of current smoking, hypertension, total cholesterol, HDL cholesterol, glycemic control of diabetes, duration of diabetes, and proteinuria. This suggests the presence of common background pathways for diabetic microvascular and macrovascular disease other than those included in the conventional risk assessment of cardiovascular disease [21]. There have been several theories that tried to explain the vascular damage associated with DM because hyperglycemia alone could not explain it by itself [2125]. Hyperfunction of platelets in diabetic patients with good glycemic control has been demonstrated and increased platelet protein kinase $\mathrm{C}$ levels have been implicated in the pathogenesis of diabetic complications [26]. Diabetic patients with retinopathy produce more superoxide anion compared with DM patients without retinopathy. Stimulated leukocytes from diabetic patients with proliferative retinopathy generated superoxide anion at significantly higher rates than did those from diabetics with non-proliferative retinopathy. These results suggest that reactive oxygen species produced by leukocytes may play a role in the progression of diabetic retinopathy [27, 28]. Recent evidence suggests that high levels of bone marrow derived circulating endothelial progenitor cells contribute to the pathological neovascularization of ischemic tissues and are a critical risk factor for the development of these complications [29].

\section{Endothelial Function}

We found severe endothelial dysfunction in all 3 groups of patients with DM type II. There was no statistical difference between the groups, and all patients had a negative result (vasoconstriction) of the brachial artery diameter and the brachial artery diameter flow-mediated percent change. We could not use this test to discriminate and characterize any of the diabetic groups, neither the non-proliferative nor the proliferative retinopathy groups. Endothelial function is too sensitive (but without specificity) for discrimination between the different stages of diabetic retinal vasculopathy. The association between microvascular and macrovascular disease is not clear in diabetes mellitus; microangiopathy and macroangiopathy in DM type II frequently coexist. In order to study this association the intima media thickness (IMT) of the carotid artery and the endothelial function (flow mediated dilatation percent change [FMD\%] of the brachial artery) were examined, and levels of von Willebrand factor (vWF) and soluble intercellular adhesion molecule 1 (sICAM-1) were measured in patients with DM type II. IMT was higher in diabetic patients with retinopathy compared with patients without retinopathy, FMD\% was lower (worse endothelial dysfunction) in the retinopathy group compared with patients without retinopathy; however, levels of S-ICAM-1 and vWF were not different between the 2 groups. In a multiple regression analysis diabetic retinopathy predicted increased IMT and decreased FMD\% (worse endothelial dysfunction), and impaired endothelial function was suggested as a common denominator of pathogenesis of microvascular complications and atherosclerosis in patients with DM type II [30]. Endothelial dysfunction was significantly more severe post acute coronary syndrome in patients with DM type II compared with patients without DM type II, 3 days and 6 months after the acute event [31]. An association was found between endothelial dysfunction and microalbuminuria, and in a logistic regression analysis $\mathrm{FMD} \%$ was the only variable independently related to microalbuminuria [32].

\section{Height and Diabetes Mellitus}

Patients with diabetes mellitus were shorter than the control group; however, no height difference was 
observed within the diabetic patients' groups. A cross sectional analysis 7424 adults aged $40-74$ years (from the NHANES III survey 1988-1994) showed that the shorter height and leg length and lower leg-to-height ratio were associated with higher percent body fat, especially in women. The relative rate of diabetes mellitus type 2 was higher among shorter individuals [33]. Other studies established an association between short stature and risk of insulin resistance [34, 35] and glucose intolerance [36, 37]. In the Finnish Diabetic Nephropathy (FinnDiane) study, patients with type I diabetes mellitus that were in the lowest quartile of adult height had increased risks of prevalent diabetic nephropathy and laser treated retinopathy [38]. In the Diabetes Control and Complications Trial (DCCT) patients with type II diabetes mellitus who were in the lowest quartile of adult height had increased risks of incident diabetic nephropathy and proliferative retinopathy [38]. Impaired growth and development in utero and during early childhood may lead to metabolic diseases in adulthood, with features of insulin resistance, thereby providing a possible link between growth, final stature, and diabetic complications [33]. There are three potential pathways linking impaired pre-pubertal growth to the risk of obesity and diabetes mellitus in middle age: 1 . Being breast fed and higher energy intake at 4 years of age are associated with longer leg length in adulthood [39]. Being breast-fed may also lower the long-term risk of obesity and diabetes mellitus type II [40]. 2. Hormonal factors relevant to growth, like Insulin-growth factor-I (during fetal and childhood growth), that appears to predict a lower risk of diabetes in adulthood [41]. 3. The intrauterine environment, which could influence both stature and the subsequent risk of diabetes via fetal programming of metabolism [42].

\section{Study Limitations}

The relatively small group of patients and the significantly younger age of subjects in the control group limit our ability to have firm conclusions. Larger studies with more age-matched controls should be sought and pursued in the near future.

\section{SUMMARY}

All patients with DM type II in our study had severe endothelial dysfunction, higher BMls, lower stature, and larger waist circumferences. We could not find clinical markers and vascular responsiveness markers that could distinguish between subgroups of patients with Diabetes Mellitus that could help define staging of diabetic retinopathy or could predict future microvascular disease progression.

\section{REFERENCES}

[1] Frank RN. Diabetic Retinopathy. N Engl J Med 2004; 350: 48-58. http://dx.doi.org/10.1056/NEJMra021678

[2] Klein R, Klein BEK, Moss SE, Davis MD, DeMets DL. The Wisconsin Epidemiologic Study of Diabetic Retinopathy. II. Prevalence and risk of diabetic retinopathy when age at diagnosis is less than 30 years. Arch Ophthalmol 1984; 102: 520-6.

http://dx.doi.org/10.1001/archopht.1984.01040030398010

[3] Idem. The Wisconsin Epidemiologic Study of Diabetic Retinopathy. III. Prevalence and risk of diabetic retinopathy when age at diagnosis is 30 or more years. Arch Ophthalmol 1984; 102: 527-32.

http://dx.doi.org/10.1001/archopht.1984.01040030405011

[4] Van Hecke MV, Dekker JM, Stehouwer CDA, Polak BCP Fuller $\mathrm{JH}$, Sjolie AK, et al. Diabetic retinopathy is associated with mortality and cardiovascular disease incidence. The EURODIAB Prospective Complications Study. Diabetes Care 2005; 28: 1383-9.

http://dx.doi.org/10.2337/diacare.28.6.1383

[5] Torffvit O, Lovestam-Adrian M, Agardh E, Agardh CD. Nephropathy, but not retinopathy, is associated with the development of heart disease in type I diabetes: a 12-year observation study of 462 patients. Diabet Med 2005; 22: 7239.

http://dx.doi.org/10.1111/j.1464-5491.2005.01476.x

[6] Klein BE, Klein R, McBride PE, Cruickshanks KS, Palta M, Knudtson MD, et al. Cardiovascular disease, mortality, and retinal microvascular characteristics in type I diabetes: Wisconsin epidemiology study of diabetic retinopathy. Arch Intern Med 2004; 164: 1917-24.

http://dx.doi.org/10.1001/archinte.164.17.1917

[7] Cusick M, Meleth AD, Agron E, Fisher MR, Reed GF, Knatterud GL, et al. Associations of mortality and diabetes complications in patients with type I and type II diabetes: early treatment diabetic retinopathy study report no. 27. Diabetes Care 2005; 28: 617-25.

http://dx.doi.org/10.2337/diacare.28.3.617

[8] Hanis CL, Chu HH, Lawson K, Hewett-Emmett D, Barton SA, Schull WJ, et al. Mortality of Mexican Americans with NIDDM. Retinopathy and other predictors in Starr Country, Texas. Diabetes Care 1993; 16: 82-9.

http://dx.doi.org/10.2337/diacare.16.1.82

[9] Miettinen H, Haffner SM, Letho S, Ronnemaa T, Pyorala K, Laakso M. Retinopathy predicts coronary heart disease events in NIDDM patients. Diabetes Care 1996; 19: 1445-8. http://dx.doi.org/10.2337/diacare.19.12.1445

[10] Van Hecke MV, Dekker JM, Nijpels G, Moll AC, Van Leiden $\mathrm{HA}$, Heine RJ, et al. Retinopathy is associated with cardiovascular and all-cause mortality in both diabetic and non-diabetic subjects. The Hoorn study. Diabetes Care 2003; 26: 2958-9. http://dx.doi.org/10.2337/diacare.26.10.2958

[11] Fuller JH, Stevens LK, Wang SL. Risk factors for cardiovascular mortality and morbidity: the WHO Multinational Study of Vascular Disease in Diabetes. Diabetologia 2001; 44: S54-S64. http://dx.doi.org/10.1007/PL00002940

[12] Klein R, Klein BEK, Moss SE, Cruickshanks KJ. Association of ocular disease and mortality in a diabetic population. Arch Ophthalmol 1999; 117: 1487-95.

http://dx.doi.org/10.1001/archopht.117.11.1487 
[13] Juutilainen A, Letho S, Ronnemaa T, Pyorala K, Laakso M. Retinopathy predicts cardiovascular mortality in type 2 diabetic men and women. Diabetes Care 2007; 30: 292-9. http://dx.doi.org/10.2337/dc06-1747

[14] Targher G, Bertolini L, Zenari L, Lippi G, Pichirit I, Zoppinit G, et al. Diabetic retinopathy is associated with an increased incidence of cardiovascular events in type 2 diabetic patients. Diabetic Med 2008; 25: 45-50. http://dx.doi.org/10.1111/j.1464-5491.2007.02327.x

[15] Wilkinson CP, Ferris FL, Klein RE, Lee PP, Agardh CD, Davis M, et al. Global Diabetic Retinopathy Project Group. Proposed international clinical diabetic retinopathy and diabetic macular edema disease severity scales. Ophthalmology 2003; 110: 1677-82. http://dx.doi.org/10.1016/S0161-6420(03)00475-5

[16] Van Hecke MV, Dekker JM, Stehouwer CD, Polak BC, Fuller $\mathrm{JH}$, Sjolie AK, et al. Diabetic retinopathy is associated with mortality and cardiovascular incidence: the EURODIAB prospective complications study. Diabetes Care 2005; 28: 1383-9.

http://dx.doi.org/10.2337/diacare.28.6.1383

[17] Nathan DM, Cleary PA, Backlund JY, Genuth SM, Lachin $\mathrm{JM}$, Orchard TJ, et al. Intensive diabetes treatment and cardiovascular disease in patients with type 1 diabetes. $\mathrm{N}$ Engl J Med 2005; 353: 2643-53.

http://dx.doi.org/10.1056/NEJMoa052187

[18] Klein R, Moss SE, Klein BE, DeMets DL. Relation of ocular and systemic factors to survival in diabetes. Arch Intern Med 1989; 149: 266-72.

http://dx.doi.org/10.1001/archinte.1989.00390020016004

[19] Targher G, Bertolini L, Tessari R, Zenari L, Arcaro G. Retinopathy predicts future cardiovascular events among type 2 diabetic patients: the Valpolicella Heart Diabetes Study (letter). Diabetes Care 2006; 29: 1178. http://dx.doi.org/10.2337/dc06-0233

[20] Van Hecke MV, Dekker JM, Nijpels G, Moll AC, Van Leiden $\mathrm{HA}$, Heine RJ, et al. Retinopathy is associated with cardiovascular and all-cause mortality in both diabetic and nondiabetic subjects: the Hoorn Study (letter). Diabetes Care 2003; 26: 2958.

http://dx.doi.org/10.2337/diacare.26.10.2958

[21] Juutilainen A, Lehto S, Ronnemaa T, Pyorala K, Laakso M. Retinopathy predicts cardiovascular mortality in type 2 diabetic men and women. Diabetes Care 2007; 30: 292-9. http://dx.doi.org/10.2337/dc06-1747

[22] Wang JJ, Liew G, Wong TY, Smith W, Klein R, Leeder S, Mitchell $P$. Retinal vascular caliber and the risk of coronary heart disease-related death. Heart 2006; 92: 1583-7.

http://dx.doi.org/10.1136/hrt.2006.090522

[23] Wong TY, Klein R, Couper DJ, Couper LS, SHahar E, Hubbard LD, et al. Retinal microvascular abnormalities and incident stroke: the Atherosclerosis Risk in Communities Study. Lancet 2001; 358: 1134-40.

http://dx.doi.org/10.1016/S0140-6736(01)06253-5

[24] Wong TY, Klein R, Sharrett AR, Duncan BB, Couper DJ, Tielsch JM, et al. Retinal arteriolar narrowing and risk of coronary heart disease in men and women: the Atherosclerosis Risk in Communities Study. JAMA 2002; 287: 1153-9.

http://dx.doi.org/10.1001/jama.287.9.1153

[25] Wong TY, Rosamond W, Chang PP, Couper DJ, Sharrett AR, Hubbard LD, et al. Retinopathy and risk of congestive heart failure. JAMA 2005; 293: 63-9. http://dx.doi.org/10.1001/jama.293.1.63

[26] Kajita K, Ishizuka T, Miura A, Kanoh Y, Ishizawa M, Kimura $\mathrm{M}$, et al. Increased platelet aggregation in diabetic patients with microangiopathy despite good glycemic control. Platelets 2001 ; 12(6): 343-51.

http://dx.doi.org/10.1080/09537100120078386
[27] Abu el-Asrar AM, Soliman RT, al Amro SA, al-Shammary FJ. Production of superoxide anion by polymorphonuclaer leukocytes from diabetic patients with or without diabetic retinopathy. Doc Ophthalmol 1995-1996; 91(3): 243-54. http://dx.doi.org/10.1007/BF01204175

[28] De La Cruz JP, Moreno A, Guerrero A, Ortega G, GonzalezCorrea JA, Sanchez de la Cuesta F. Nitric oxide-cGMP and prostacyclin-cAMP pathways in patients with tpe II diabetes and different types of retinopathy. Pathophysiol Haemost Thromb 2002; 32(1): 25-32. http://dx.doi.org/10.1159/000057285

[29] Tan K, Lessieur E, Cutler A, Nerone P, Vasanji A, Asosingh $\mathrm{K}$, et al. Impaired function of circulating CD34+CD45- cells in patients with proliferative diabetic retinopathy. Experimental Eye Res 2010; 91: 229-37. http://dx.doi.org/10.1016/j.exer.2010.05.012

[30] Maleki MT, Osmenda G, Walus-Miarka M, Skupien J, Cyganek K, Mirkiewicz-Sieradzeka B, et al. Retinopathy in type 2 diabetes mellitus is associated with increased intimamedia thickness and endothelial dysfunction. Eur $\mathrm{J}$ Clin Invest 2008; 38(12): 925-30. http://dx.doi.org/10.1111/j.1365-2362.2008.02051.x

[31] Bissinger A, Grycewicz T, Grabowicz W, Lubinski A. Endothelial function and left ventricular remodeling in diabetic and non-diabetic patients after acute coronary syndrome. Med Sci Monit 2011; 17(2): CR73-77. http://dx.doi.org/10.12659/MSM.881390

[32] Baykan M, Erdogan T, Erem C, Hacihasanoglu A, Gedikli O, Kucukosmanoglu $\mathrm{M}$, et al. The relationship between flow mediated dilatation and left ventricular function in type 2 diabetic patients with microalbuminuria. Endocrine 2006; 30(2): 197-202. http://dx.doi.org/10.1385/ENDO:30:2:197

[33] Asao K, Kao L, Baptiste-Roberts K, Bandeen-Roche K, Erlinger TP, Brancati FL. Short stature and the risk of adiposity, insulin resistance, and type 2 diabetes in middle age. Diabetes Care 2006; 29: 1632-7. http://dx.doi.org/10.2337/dc05-1997

[34] Guerrero-Igea FJ, Lepe-Jimenez JA, Garrido-Serrano A, Palomo-Gil S. Association among hyperinsulinemia, family history of diabetes, and diminutive stature in normoglycemic premenopausal women (letter). Diabetes Care 2001; 24: 602-3.

http://dx.doi.org/10.2337/diacare.24.3.602-a

[35] Smith GD, Greenwood R, Gunnell D, Sweetnam P, Yarnell J, Elwood P. Leg length, insulin resistance, and coronary heart disease risk: the Caerphilly Study. J Epidemiol Community Health 2001; 55: 867-72. http://dx.doi.org/10.1136/jech.55.12.867

[36] Lawlor DA, Ebrahim S, Davey SG. The association between components of adult height and type II diabetes and insulin resistance: British Women's Heart and Health Study. Diabetologia 2002; 45: 1097-106. http://dx.doi.org/10.1007/s00125-002-0887-5

[37] Njolstad I, Arnesen E, Lund-Larsen PG. Sex differences in risk factors for clinical diabetes mellitus in a general population: a 12 year follow up of the Finnmark Study. Am J Epidemiol 1998; 147: 49-58. http://dx.doi.org/10.1093/oxfordjournals.aje.a009366

[38] Waden J, Forsblom C, Thorn LM, Saraheimo M, RosengardBarlund $\mathrm{M}$, Heikkila $\mathrm{O}$, et al. Adult stature and diabetes complications in patients with type 1 diabetes. Diabetes 2009; 58: 1914-20.

http://dx.doi.org/10.2337/db08-1767

[39] Arenz S, Ruckerl R, Koletzko B, von Kries R. Breast feeding and childhood obesity: a systematic review. Int J Obes Relat Metab Disorde 2004; 28: 1247-56.

http://dx.doi.org/10.1038/sj.ijo.0802758 
[40] Pettitt DJ, Forman MR, Hanson RL, Knowler WC, Bennett $\mathrm{PH}$. Breastfeeding and incidence of non-insulin dependent diabetes mellitus in Pima Indians. Lancet 1997; 350: 166-8. http://dx.doi.org/10.1016/S0140-6736(96)12103-6

[41] Rosenfeld RG. Insulin like growth factors and the basis of growth. N Engl J Med 2003; 349: 2184-6. http://dx.doi.org/10.1056/NEJMp038156
[42] Barker DJ, Gluckman PD, Godfrey KM, Harding JE, Owens JA, Robinson JS. Fetal nutrition and cardiovascular disease in adult life. Lancet 1993; 341: 938-41. http://dx.doi.org/10.1016/0140-6736(93)91224-A 